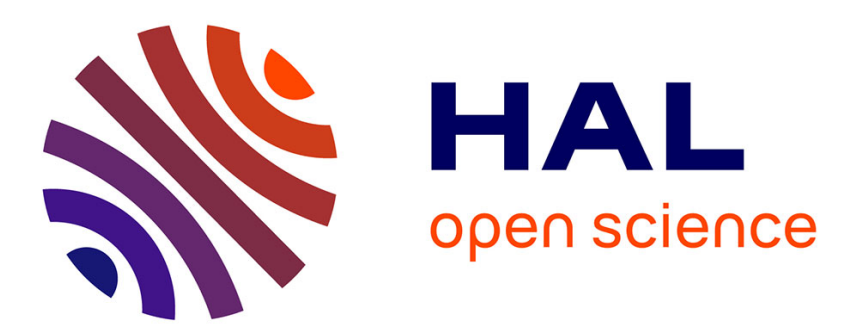

\title{
Fast and continuous synthesis of nanostructured iron spinel in supercritical water: influence of cations and citrates
}

Lionel Maurizi, F. Bouyer, M. Ariane, R. Chassagnon, N. Millot

\section{- To cite this version:}

Lionel Maurizi, F. Bouyer, M. Ariane, R. Chassagnon, N. Millot. Fast and continuous synthesis of nanostructured iron spinel in supercritical water: influence of cations and citrates. RSC Advances, 2014, 4 (86), pp.45673-45678. 10.1039/C4RA08562K . hal-02163438

\section{HAL Id: hal-02163438 \\ https://hal.science/hal-02163438}

Submitted on 14 Mar 2021

HAL is a multi-disciplinary open access archive for the deposit and dissemination of scientific research documents, whether they are published or not. The documents may come from teaching and research institutions in France or abroad, or from public or private research centers.
L'archive ouverte pluridisciplinaire HAL, est destinée au dépôt et à la diffusion de documents scientifiques de niveau recherche, publiés ou non, émanant des établissements d'enseignement et de recherche français ou étrangers, des laboratoires publics ou privés. 
Fast and continuous synthesis of nanostructured iron spinel in supercritical water: influence of cations and citrates

L. Maurizi ${ }^{a \dagger}$, F. Bouyer, ${ }^{a}$ M. Ariane, ${ }^{a}$ R. Chassagnon ${ }^{a}$ and N. Millot ${ }^{\mathrm{a}^{*}}$

Spinel iron oxide nanoparticles were obtained under supercritical water conditions in a continuous and fast (less than $10 \mathrm{~s}$ ) way by modifying the initial stoichiometric $\mathrm{Fe}^{\mathrm{II}} / \mathrm{Fe}^{\mathrm{III}}$ molar ratio from $(1 / 2)$ to $(3 / 0)$, without base solution, and using citrates directly with iron precursors. This result opens the way of an economical and environmentally benign approach to synthesize superparamagnetic iron oxide nanoparticles (SPIONs) in important yields.

\section{Introduction}

Metallic oxide nanoparticles are more and more used as-synthesized for different applications such as catalysis ${ }^{1,2}$, pollution treatments, or with biocompatible coatings ${ }^{3-6}$ for bio-applications such as Magnetic Resonance Imaging (MRI) ${ }^{7-10}$ or hyperthermia ${ }^{11-13}$. Nowadays, adapting their laboratory's fabrication to a more industrial production is a huge challenge ${ }^{14}$. Hydrothermal syntheses may be an appropriate route to solve this problem either by batch ${ }^{15-18}$ or continuous way ${ }^{19-24}$. In parallel, a derivative method was developed using the supercritical properties of water. Above critical temperature and pressure values $(\mathrm{P}>$ $22 \mathrm{MPa}$ and $\mathrm{T}>647 \mathrm{~K}$ ), the properties of water drastically change ${ }^{25}$. The dissociation constant of water is much smaller (roughly 3 times) in supercritical conditions than in normal conditions ${ }^{26,27}$ leading to a higher dissolution power for organic compounds which is ideal for organic pollutants extraction ${ }^{28}$. The small dielectric constant of supercritical water allows synthesis of metallic oxide nanoparticles without any base ${ }^{29-33}$ and in a very short reaction time ${ }^{23}$. However, in the case of iron oxide nanoparticles the hematite phase is usually obtained ${ }^{23,29,34}$ because of the oxidative properties of supercritical water. The same trend was also observed with hydrothermal conditions. In a recent paper, it was shown that citrate ions, due to their anti-oxidative properties, prevented the oxidation of iron oxide and stabilized the magnetite $\left(\mathrm{Fe}_{3} \mathrm{O}_{4}\right)$ phase ${ }^{35}$. In addition, citrates allowed the control of the crystallite growth ${ }^{35,36}$.

In this paper, iron oxide nanoparticles were synthesized in a continuous supercritical water process without base solution. By tuning the molar ratio of $\mathrm{Fe}^{\mathrm{II}} / \mathrm{Fe}^{\mathrm{III}}$ and by adding citrates to the precursor solution, the iron oxide phase shifted from hematite phase $\left(\alpha-\mathrm{Fe}_{2} \mathrm{O}_{3}\right)$ to exclusive spinel phase $\left(\mathrm{Fe}_{3(1-\delta)} \mathrm{O}_{4}\right)$ opening the way of a production of superparamagnetic iron oxide nanoparticles (SPIONs) in supercritical water, in a continuous way and so with important yields.

\section{Material \& Methods}

The hydrothermal continuous process working in supercritical water conditions was described elsewhere $21,29,37,38$. In order to investigate the influence of the oxidation degree of iron cations, three different conditions of reaction were set up. First of all, a molar ratio $\mathrm{Fe}^{\mathrm{II}} / \mathrm{Fe}^{\mathrm{III}}(1 / 2)$ was prepared by dissolution of sulfate iron precursors in water $\left(8.10^{-3} \mathrm{M} / 16.10^{-3} \mathrm{M}\right)$. The second iron cations solution was prepared with only $\mathrm{Fe}^{\mathrm{II}}(3 / 0)$ at a concentration of $24 \cdot 10^{-3} \mathrm{M}$. The last solution was prepared with $\mathrm{Fe}^{\mathrm{II}}$ too (3/0) plus citrates in a molar ratio (1/1) $\left(24.10^{-3} \mathrm{M}\right.$ of $\mathrm{Fe}^{\mathrm{II}} / 24.10^{-3} \mathrm{M}$ of citrates). All syntheses were realized in the absence of base. The pressure of the system was fixed at $25 \mathrm{MPa}$.

The supercritical water process (shown in Figure 1) has three lines which mixed in the in the reactor at set-up pressure and temperature. The first line was loaded with the reactants $\left(\mathrm{Fe}^{\mathrm{II}} \mathrm{Fe}^{\mathrm{III}}\right.$ and/or citrates) the 
second one with water (no basic reaction's initiator) and a third line where water was preheated at $623 \mathrm{~K}$ 39. The mixing point in the reactor was set up in supercritical water conditions $(\mathrm{P}=25 \mathrm{MPa}, \mathrm{T}=673 \mathrm{~K})$. The flow rate was fixed at $30 \mathrm{~mL} \cdot \mathrm{min}^{-1}$ to lead to a residential time of 8 seconds. At the exit of the reactor, the suspensions were rapidly cooled-down in water bath, collected and dialyzed for 48 hours against $\mathrm{HNO}_{3} 10 \mathrm{mM}$ by changing the dialyzed water every 12 hours. Then suspensions were freezedried to be characterized by X-Ray Diffraction (XRD Siemens D5000, $\lambda \mathrm{K}_{\beta} \mathrm{Cu}=1.39222 \AA$ ) which gives lattice parameters and crystallite's mean size $\left(\mathrm{d}_{\mathrm{XRD}}\right)$ using Halder and Wagner or Williamson and Hall fitting methods 40-42; Transmission Electron Microscopy (TEM: JEOL JEM-2100 LaB6 microscope) leading to TEM diameters ( $\mathrm{d}_{\mathrm{TEM}}$ ) obtained by counting around one hundred of particles on TEM pictures and Specific Surface Areas (SSA: Autosorb 1C from Quantachrome) which can lead to a mean diameter $\left(d_{\mathrm{BET}}\right)$ equal to $6000 /\left(\rho^{*} \mathrm{SSA}\right)$ where $\rho$ is the density of the particle in $\mathrm{g} \cdot \mathrm{cm}^{-3}$ and SSA is in $\mathrm{m}^{2} \cdot \mathrm{g}^{-1}$.

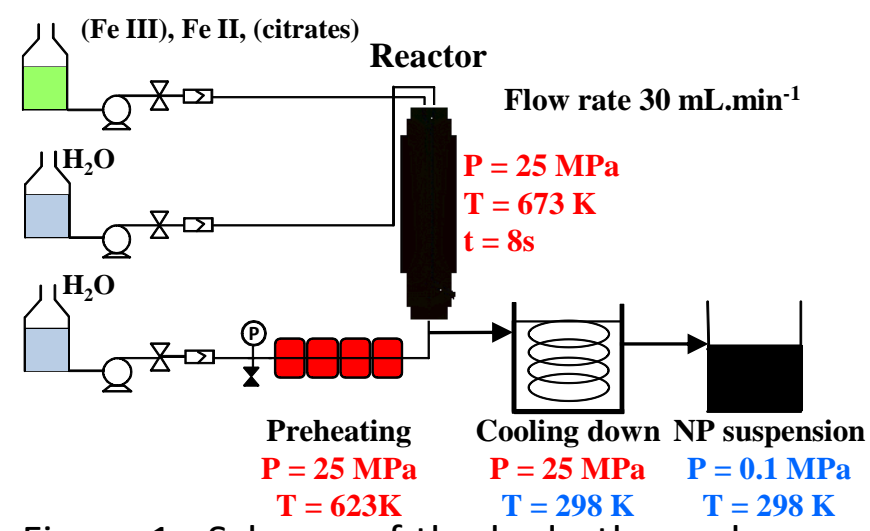

Figure 1 : Scheme of the hydrothermal process working in continuous and a supercritical water conditions ( $P>22 \mathrm{MPa}$ and $\mathrm{T}>647 \mathrm{~K})$; NP: nanoparticles

\section{Results and discussion}

XRD patterns in Figure 2-a firstly show, that the powders obtained following the 3 different conditions are crystalline iron oxide nanoparticles even without using base. With classical a $\mathrm{Fe}^{\mathrm{II}} / \mathrm{Fe}^{\mathrm{III}}$ ratio $(1 / 2)$, the final phase was the rhombohedral hematite $\left(\alpha-\mathrm{Fe}_{2} \mathrm{O}_{3}\right)$ which is the most stable iron oxide phase at high temperature ${ }^{43}$.

With only $\mathrm{Fe}^{\mathrm{II}}$ cations precursors, two phases were observed: hematite and spinel $\mathrm{Fe}_{3(1-\delta)} \mathrm{O}_{4}$ phase. Following a previous work ${ }^{43}$ about the comparison of the intensity of the (104) diffraction peak of hematite and the intensity of the (220) magnetite peak, it was possible to estimate the $\alpha-\mathrm{Fe}_{2} \mathrm{O}_{3}$ phase proportion. In the case of the synthesis without citrates, $41 \%$ of hematite was present. On this X-ray pattern, the peaks observed around $25^{\circ}$ (blue star in Figure 2-a) are due to polluting elements coming from the reactor used during this study. When $\mathrm{Fe}^{\mathrm{II}}$ cations were previously mixed with citrates in a molar ratio (1/1), the phase observed is almost exclusively the spinel one with less than $0.5 \%$ of hematite. The diffraction peaks of the powder obtained with citrates (Figure 2-b) consist of two phases corresponding to a phase with sharp peaks and a lattice parameter of $(8.397 \pm 0.001 \AA)$ and a phase with broad peaks and a lattice parameter of $(8.350 \pm 0.002 \AA)$. It reveals the simultaneous presence of large mean diameter crystallites of magnetite $\left(\mathrm{Fe}_{3} \mathrm{O}_{4}\right)$, stoichiometric spinel, and of smaller crystallites of maghemite $(\gamma$ $\mathrm{Fe}_{2} \mathrm{O}_{3}$ ), lacunary spinel. ${ }^{35,44}$ 


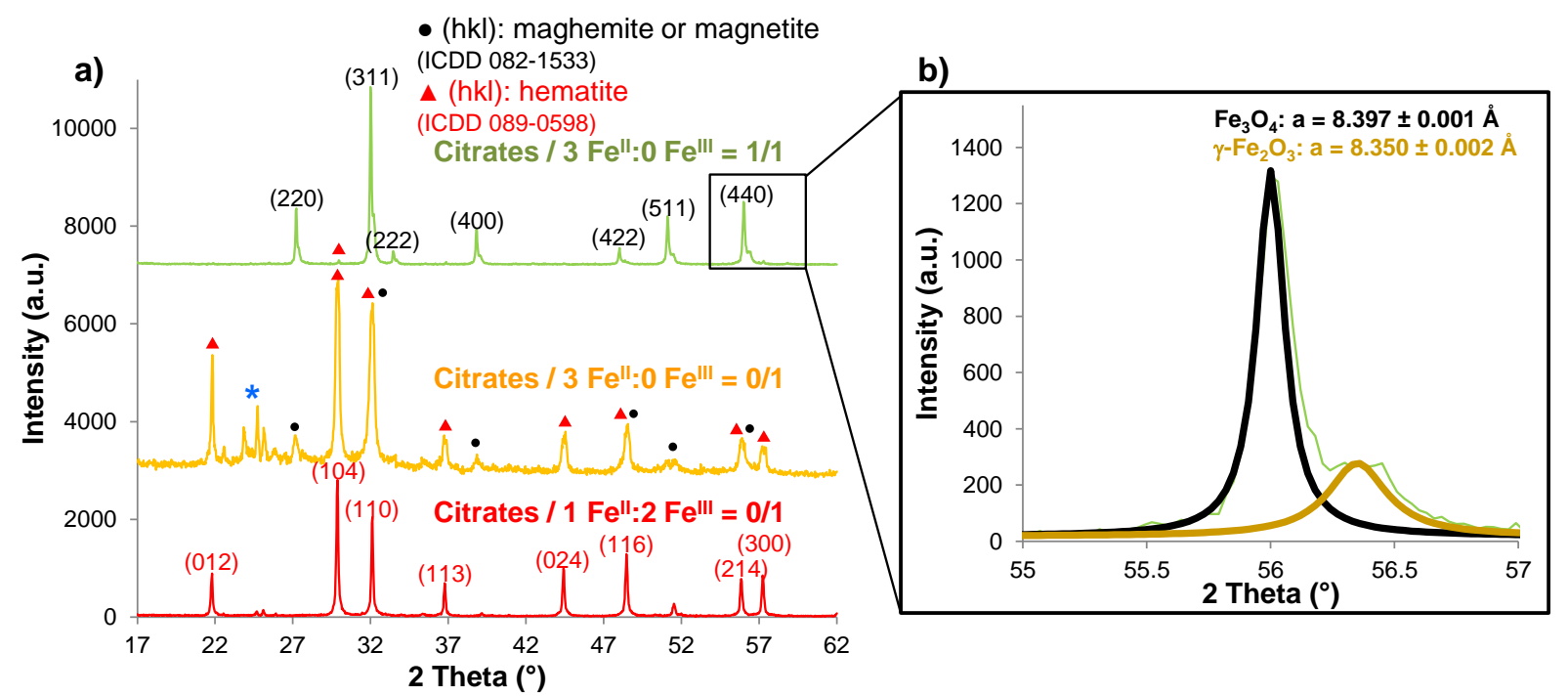

Figure 2: a) XRD patterns (arbitrary units: a.u.) of iron oxide nanoparticles obtained under continuous supercritical water conditions, without addition of base and with different iron and citrates mass ratios. International Centre for Diffraction Data (ICDD) files used were indicated; $b$ ) Zoom section of the splitting of the diffraction peak of spinel particles obtained with only $\mathrm{Fe}^{\mathrm{H}}$ precursor mixed with citrates molecules in a molar ratio (1/1). Blue star: polluting elements coming from the reactor

TEM observations (Figure 3) of the three powders confirmed the previous observations. With $\mathrm{Fe}^{\mathrm{II}} / \mathrm{Fe}^{\mathrm{III}}$ molar ratio (1/2), the particles look like hexagonal or spherical hematite nanoparticles (see Figure 3-a) and the TEM size $\left(\mathrm{d}_{\text {TEM }}=72 \pm 6 \mathrm{~nm}\right)$ reported in Table 1 is close to the size calculated from the XRD patterns $\left(\mathrm{d}_{\mathrm{XRD}}=69 \pm 1 \mathrm{~nm}\right)$. The insert zoom section in the Figure 3-a, HRTEM image showing (012) planes, proved also the presence of the crystalline hematite phase. The hematite specific surface area (SSA) is around $12 \mathrm{~m}^{2} \cdot \mathrm{g}^{-1}$ leading to a mean diameter $\left(\mathrm{d}_{\mathrm{BET}}\right)$ of $94 \pm 15 \mathrm{~nm}$ within the same range as the TEM and XRD diameter measurements. With Fe ${ }^{\mathrm{II}}$ only, TEM pictures show nanoparticles around 100 $\mathrm{nm}$, from hematite phase, correlated with XRD diameter of $\alpha-\mathrm{Fe}_{2} \mathrm{O}_{3}$. These hematite particles are surrounded by very small elongated spinel crystalline particles (zoom section Figure 3-b) around 4 to 6 $\mathrm{nm}$. This hypothesis is verified with HRTEM imaging of one of this elongated crystallites showing the (220) plans of spinel iron oxide phase. Furthermore selected area diffractions were done on these particles during TEM imaging and analyses (Figure SI given in ESI); these analyses also proved the spinel structures of these small particles. No attempt of statistical analysis of the diameter was undertaken because of the large agglomeration of those small particles. This second phase was also observed in XRD (Figure 2-a). However, regarding the XRD pattern, it was too complicated to dessumate the contribution of the two iron oxide phases present and then to obtain XRD diameters. Nevertheless the high value of the average specific area of this powder, $157 \pm 1 \mathrm{~m}^{2} \cdot \mathrm{g}^{-1}$ proves the presence of very small nanoparticles (around $8 \mathrm{~nm}$ ), here spinel ones, because hematite is the thermodynamically stable iron oxide phase at high temperature for grain sizes larger than $20 \mathrm{~nm}^{45}$. With $\mathrm{Fe}^{\mathrm{II}}$ and citrates in a (1/1) molar ratio, the particles observed in TEM are poly-dispersed from few nanometers to half a micron (Figure 3-c). Moreover, the fit of the assymetric diffraction peaks (Figures 2-a and 2-b and Table 1), suggest the presence of two populations of nanoparticles: maghemite nanoparticles of $32 \pm 6 \mathrm{~nm}$ and magnetite nanoparticles of $106 \pm 19 \mathrm{~nm}$. Finally, the average surface area of this powder around $7 \pm 1 \mathrm{~m}^{2} \cdot \mathrm{g}^{-1}$ proved the presence of bigger particles, than that fitted by XRD, with an average diameter around $170 \mathrm{~nm}$, which is confirmed by TEM observations (Figure 3-c). For the particles synthesized from $\mathrm{Fe}^{\mathrm{II}}$ only with or without citrates, no mean TEM diameter $\left(\mathrm{d}_{\mathrm{TEM}}\right)$ was calculated because of the difficulty to correctly distinguished boundaries and/or quantified very small crystallites.

In the light of the above results, it is possible to propose a synthesis mechanism of iron oxide nanoparticles from iron precursors in supercritical water. The formation of relatively monodispersed 
hematite nanoparticles with usual stoichiometric molar ratio $\mathrm{Fe}^{\mathrm{II}} / \mathrm{Fe}^{\mathrm{III}}(1 / 2)$ can be explained by the quasi instantaneously oxidation of $\mathrm{Fe}^{\mathrm{II}}$ to $\mathrm{Fe}^{\mathrm{III}}$ at high temperature and pressure $(\mathrm{T}=673 \mathrm{~K}, \mathrm{P}=25 \mathrm{MPa})$. Even in classical hydrothermal route, using only $\mathrm{Fe}^{\mathrm{III}}$ cations in aqueous media usually leads to the formation of $\alpha-\mathrm{Fe}_{2} \mathrm{O}_{3}{ }^{46,47}$. In fact, hematite phase is commonly obtained in supercritical water conditions $23,29,34,48$ using $\mathrm{Fe}^{\mathrm{III}}$ precursors. Moreover, as previously said, hematite phase is the thermodynamically stable iron oxide phase at high temperature and when the grains are larger than $20 \mathrm{~nm}^{45}$. It can also be obtained by heat treatment of iron hydroxides ${ }^{49}$ or spinel particles ${ }^{41}$.

To limit the oxidation of $\mathrm{Fe}^{\mathrm{II}}$ and to stabilize the spinel phase, only $\mathrm{Fe}^{\mathrm{II}}$ precursors were used with or without citrates addition. In these cases, two phases of iron oxide nanoparticles were obtained. Without citrates, a mixture of spinel particles (59\% mass proportion) and hematite particles (41\% mass proportion) were synthesized. Then, with citrates, an exclusive spinel phase (hematite mass ratio $<0.5 \%$ ) was obtained with two types of particles: small maghemite particles (around $30 \mathrm{~nm}$ in diameter) and bigger magnetite particles (around $100 \mathrm{~nm}$ in average but with some at hundreds of $\mathrm{nm}$ to half microns).

The mix of metallic precursors with organic chelates ${ }^{14,50-52}$ is the usual method described in literature to synthesize spinel particles in supercritical water. In our study, $\mathrm{Fe}_{3(1-\delta)} \mathrm{O}_{4}$ particles were obtained using $\mathrm{Fe}^{\mathrm{II}}$ precursor previously mixed with citrates. It was demonstrated by Takami et al. ${ }^{51}$ and in a previous work of our group ${ }^{35}$ that antioxidant and chelatant properties of citrates avoid formation of $\alpha-\mathrm{Fe}_{2} \mathrm{O}_{3}$ and crystallite's growth during hydrothermal syntheses (bellow the critical point). Thanks to this new study, we can attest that it is also the case in supercritical water. This method is faster, cheaper and more environmental friendly that classical organic chelates syntheses. 
Table 1: Physicochemical properties of iron oxide nanoparticles obtained under continuous supercritical conditions for different iron and citrates mass ratios

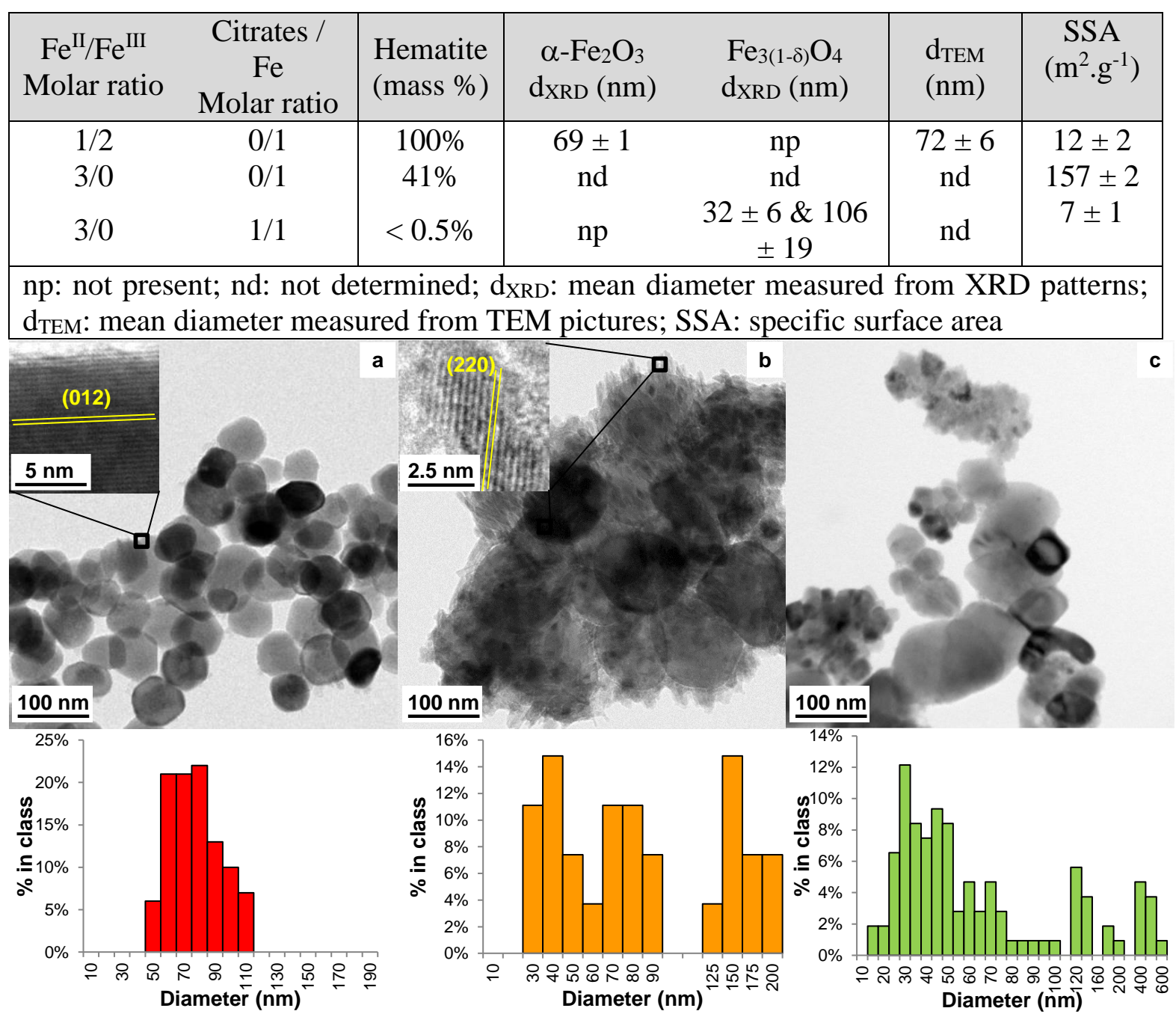

Figure 3: TEM pictures (with zoom section on top) and TEM diameters distributions of iron oxide nanoparticles synthesized under continuous supercritical water conditions with ( $\left.\mathrm{Fe}^{\prime \prime} / \mathrm{Fe}^{\mathrm{III}}\right)$ molar ratio: a) $(1 / 2)$; b) $(3 / 0)$; c) $(3 / 0)+$ citrates (molar ratio citrates $/ \mathrm{Fe}=1 / 1)$

Regarding the two biphasic distributions obtained with $\mathrm{Fe}^{\mathrm{II}}$ precursors (with or without citrates), one of the hypotheses could be the formation of a sub-stoichiometric molar ratio of $\mathrm{Fe}^{\mathrm{II}} / \mathrm{Fe}^{\mathrm{III}}$ leading to the formation of spinel structured iron oxide particles. A study of Tronc et al. ${ }^{54}$ demonstrated that with substoichiometric iron cations molar ratio, it was possible to obtain spinel structured particles. When Metal $^{\mathrm{II}} / \mathrm{Fe}^{\mathrm{III}}>0.2$, they obtained metallic hydroxide leading to spinel structured particles. We also observed spinel iron oxide confirming this hypothesis of sub-stoichiometric $\mathrm{Fe}^{\mathrm{II}} / \mathrm{Fe}^{\mathrm{III}}$ molar ratio. Moreover no goethite phase $(\alpha-\mathrm{FeOOH})$, which should appear when $\mathrm{Fe}^{\mathrm{II}} / \mathrm{Fe}^{\mathrm{III}}<0.1$, was observed. Jolivet et al. ${ }^{55}$ also explained that in sub-stoichiometric $\mathrm{Fe}^{\mathrm{II}} / \mathrm{Fe}^{\mathrm{III}}$ molar ratio conditions (1/6) and 24 hours after Ostwald ripening at ambient conditions, two types of particles were synthesized: small particles (few $\mathrm{nm}$ ) of maghemite and large particles (100 to $150 \mathrm{~nm}$ ) of magnetite. The big particles grew from a dissolutionreprecipitation process at a quasi-stoichiometric ratio when the small particles are poor in $\mathrm{Fe}^{\mathrm{II}}$ and are formed by $\mathrm{Fe}^{\mathrm{II}}$ adsorption on ferric hydroxide. The stoichiometry of the $\mathrm{Fe}^{\mathrm{II}}$ seems to be crucial in the formation of spinel structured nanoparticles formation in classical aqueous route. Under supercritical 
water conditions, the same observations were done but with very short reaction time $(8 \mathrm{~s})$. When the $\mathrm{Fe}^{\mathrm{II}}$ cations entered the reactor, many of them should be oxidized in $\mathrm{Fe}^{\mathrm{III}}$ to give a sub-stoichiometric molar ratio $\left(\mathrm{Fe}^{\mathrm{II}} / \mathrm{Fe}^{\mathrm{III}}\right.$ ) leading to the formation of spinel structured $\mathrm{Fe}_{3(1-\delta)} \mathrm{O}_{4}$ close to maghemite. Under supercritical water conditions, the Ostwald ripening was accelerated and led to the formation of two populations of spinel particles: small maghemite particles and large magnetite particles. Then, because maghemite particles are already at their maximal oxidized state and certainly because of their small size, they did not turn into other phase. However, the big magnetite particles either oxidized to hematite without citrates or continue to grow larger preventing from oxidizing by citrates molecules as already observed in hydrothermal continuous conditions bellow supercritical point ${ }^{35}$. Moreover, adding citrates should have prevented the oxidation of $\mathrm{Fe}^{\mathrm{II}}$ precursors and increased the sub-stoichiometric $\mathrm{Fe}^{\mathrm{II}} / \mathrm{Fe}^{\mathrm{III}}$ ratio compared to without citrates. This could also explain the absence of hematite phase and the presence of bigger magnetite particles. A summarizing mechanism of the synthesis of spinel structured particles under supercritical water conditions is given in Figure 4. It was shown that citrates ions played a role in the phase transformation or iron oxide nanoparticles but certainly because of the high temperatures conditions of supercritical water, part of these ions should have been degraded. It certainly decreased the quantity of citrates in the system and did not permit to stabilize the nanoparticles or to decrease either their mean diameter or polydispersity as already observed in hydrothermal continuous synthesis ${ }^{35}$ below the supercritical field.

$$
\begin{aligned}
& 1 \mathrm{Fe}^{\mathrm{II}}+2 \mathrm{Fe}^{\mathrm{III}} \stackrel{\mathrm{SC \textrm {H } _ { 2 } \mathrm { O }}}{\longrightarrow} 3 \mathrm{Fe}^{I I I} \stackrel{\mathrm{SC} \mathrm{H}_{2} \mathrm{O}}{\longrightarrow} \mathrm{\alpha} \mathrm{Fe}_{2} \mathrm{O}_{3} \\
& 3 \mathrm{Fe}^{I I I} \stackrel{S C \mathrm{H}_{2} \mathrm{O}}{\longrightarrow}(3-\varepsilon) F e^{I I I}+\varepsilon F e^{I I}\left\{\begin{array}{l}
\left.\stackrel{\text { no citrates }}{\longrightarrow} \mathrm{Fe}_{3(\mathbf{1}}-\delta\right) \boldsymbol{O}_{4}+\alpha \boldsymbol{F e}_{2} \boldsymbol{O}_{3} \\
\underset{\text { citrates }}{\longrightarrow} \gamma \mathrm{Fe}_{2} \mathrm{O}_{3}+\boldsymbol{F e}_{3} \boldsymbol{O}_{4}
\end{array}\right.
\end{aligned}
$$

Figure 4: Summary of the synthesis mechanism proposed for the synthesis of iron oxide nanoparticles under continuous supercritical water conditions for different iron and citrates precursor's ratios; $\mathrm{SC} \mathrm{H}_{2} \mathrm{O}$ : supercritical water; $\varepsilon<0.5$

\section{Conclusions}

First of all, it was possible to obtain in this work, iron oxide nanoparticles using a continuous hydrothermal water synthesis process working under supercritical water conditions without using any base solution and in a very short reaction time $(8 \mathrm{~s})$. By changing the initial $\mathrm{Fe}^{\mathrm{II}} / \mathrm{Fe}^{\mathrm{III}}$ stoichiometric molar ratio from (1/2) to (3/0), the particles structure changed from hematite only to a mixture of spinel and hematite phases. Then by adding citrates ions to $\mathrm{Fe}^{\mathrm{II}}$ precursors in a molar ratio of $(1 / 1)$, the phases obtained were exclusively spinel structures with small maghemite $\left(\gamma-\mathrm{Fe}_{2} \mathrm{O}_{3}\right)$ particles and sub-micronic magnetite $\left(\mathrm{Fe}_{3} \mathrm{O}_{4}\right)$ particles. The citrates prevent the oxidation $\mathrm{Fe}^{\mathrm{II}}$ to $\mathrm{Fe}^{\mathrm{III}}$ even in the supercritical field. By increasing the initial molar ratio of citrates / iron, it mays allow the stabilization of smaller and monodisperse magnetite nanoparticles in a continuous supercritical water process.

\section{Acknowledgments}

We gratefully thank both CNRS (Centre National de la Recherche Scientifique) and Conseil Regional de Bourgogne for financial support.

\section{Notes and references}

${ }^{a}$ Laboratoire Interdisciplinaire Carnot de Bourgogne, UMR 6303 CNRS/Université de Bourgogne, 9 avenue Alain Savary, BP 47870, 21078 Dijon cedex, France

* Corresponding author: nmillot@u-bourgogne.fr

$\dagger$ Current address: Powder Technology Laboratory, Ecole Polytechnique Federale de Lausanne (EPFL), CH-1015 Lausanne, Switzerland 
1. D. L. Huber, Small, 2005, 1, 482-501.

2. G. P. Van der Laan and A. Beenackers, Catal. Rev. - Sci. Eng., 1999, 41, 255-318.

3. B. Basly, D. Felder-Flesch, P. Perriat, C. Billotey, J. Taleb, G. Pourroy, and S. Begin-Colin, Chem. Commun., 2010, 46, 985-987.

4. L. Maurizi, H. Bisht, F. Bouyer, and N. Millot, Langmuir, 2009, 25, 8857-8859.

5. M. Chastellain, A. Petri, and H. Hofmann, in Quantum Dots, Nanoparticles and Nanowires, ed. P. M. H. W. Z. L. GuyotSionnest, 2004, vol. 789, pp. 269-272.

6. A. Jordan, R. Scholz, P. Wust, H. Schirra, T. Schiestel, H. Schmidt, and R. Felix, J. Magn. Magn. Mater., 1999, 194, 185-196.

7. A.-L. Papa, L. Maurizi, D. Vandroux, P. Walker, and N. Millot, J. Phys. Chem. C, 2011, 115, 1901219017.

8. R. Azoulay, P. Olivier, O. Baud, C. Verney, R. Santus, P. Robert, P. Gressens, and G. Sebag, J. Magn. Reson. Imaging, 2008, 28, 1046-1052.

9. K. Nwe, L. H. Bryant, and M. W. Brechbiel, Bioconjug. Chem., 2010, 21, 1014-1017.

10. L. Maurizi, U. Sakulkhu, L. A. Crowe, V. M. Dao, N. Leclaire, J.-P. Vallée, and H. Hofmann, RSC Adv., 2014, 4, 11142-11146.

11. A. Ito, M. Shinkai, H. Honda, and T. Kobayashi, J. Biosci. Bioeng., 2005, 100, 1-11.

12. M. Chastellain, A. Petri, A. Gupta, K. v. Rao, and H. Hofmann, Adv. Eng. Mater., 2004, 6, 235241.

13. J. H. Park, K. H. Im, S. H. Lee, D. H. Kim, D. Y. Lee, Y. K. Lee, K. M. Kim, and K. N. Kim, J. Magn. Magn. Mater., 2005, 293, 328-333.

14. G. R. Patzke, Y. Zhou, R. Kontic, and F. Conrad, Angew. Chem. Int. Ed., 2011, 50, 826-859.

15. H. Hayashi and K. Torii, J. Mater. Chem., 2002, 12, 3671-3676.

16. S. Gyergyek, M. Drofenik, and D. Makovec, Mater. Chem. Phys., 2012, 133, 515-522.

17. T. J. Daou, G. Pourroy, S. Begin-Colin, J. M. Greneche, C. Ulhaq-Bouillet, P. Legare, P.

Bernhardt, C. Leuvrey, and G. Rogez, Chem. Mater., 2006, 18, 4399-4404.

18. J. Wang, J. Sun, Q. Sun, and Q. Chen, Mater. Res. Bull., 2003, 38, 1113-1118.

19. N. Millot, S. Le Gallet, D. Aymes, F. Bernard, and Y. Grin, J. Eur. Ceram. Soc., 2007, 27, 921926.

20. S.-A. Hong, S. J. Kim, K. Y. Chung, Y.-W. Lee, J. Kim, and B.-I. Sang, Chem. Eng. J., 2013, 229, 313-323.

21. N. Millot, B. Xin, C. Pighini, and D. Aymes, J. Eur. Ceram. Soc., 2005, 25, 2013-2016.

22. K. Sue, K. Murata, K. Kimura, and K. Arai, Green Chem., 2003, 5, 659-662.

23. T. Adschiri, K. Kanazawa, and K. Arai, J. Am. Ceram. Soc., 1992, 75, 1019-1022.

24. A. Aimable, B. Xin, N. Millot, and D. Aymes, J. Solid State Chem., 2008, 181, 183-189.

25. H. Weingartner and E. U. Franck, Angew. Chem.-Int. Ed., 2005, 44, 2672-2692.

26. P. E. Savage, Chem. Rev., 1999, 99, 603-621.

27. C. A. Eckert, B. L. Knutson, and P. G. Debenedetti, Nature, 1996, 383, 313-318.

28. S. B. Hawthorne, Y. Yang, and D. J. Miller, Anal. Chem., 1994, 66, 2912-2920.

29. A. Aimable, H. Muhr, C. Gentric, F. Bernard, F. Le Cras, and D. Aymes, Powder Technol., 2009, 190, 99-106.

30. R. B. Yahya, H. Hayashi, T. Nagase, T. Ebina, Y. Onodera, and N. Saitoh, Chem. Mater., 2001, 13, 842-847.

31. T. Arita, H. Hitaka, K. Minami, T. Naka, and T. Adschiri, J. Supercrit. Fluids, 2011, 57, $183-189$.

32. J. Lee and A. S. Teja, Mater. Lett., 2006, 60, 2105-2109.

33. C. Pighini, D. Aymes, N. Millot, and L. Saviot, J. Nanoparticle Res., 2007, 9, 309-315.

34. K. Sue, M. Suzuki, K. Arai, T. Ohashi, H. Ura, K. Matsui, Y. Hakuta, H. Hayashi, M. Watanabe, and T. Hiaki, Green Chem., 2006, 8, 634-638. 
35. L. Maurizi, F. Bouyer, J. Paris, F. Demoisson, L. Saviot, and N. Millot, Chem. Commun., 2011, 47, 11706-11708.

36. A. Bee, R. Massart, and S. Neveu, J. Magn. Magn. Mater., 1995, 149, 6-9.

37. F. Bernard, D. Aymes, M. Ariane, H. Muhr, and F. Demoisson, 20090720.

38. D. B. Murray, C. H. Netting, L. Saviot, C. Pighini, N. Millot, D. Aymes, and H.-L. Liu, J. Nanoelectron. Optoelectron., 2006, 1, 92-98.

39. F. Demoisson, M. Ariane, R. Piolet, and F. Bernard, Submitt. Adv. Eng. Mater., 2010.

40. T. Belin, N. Millot, F. Villieras, O. Bertrand, and J. P. Bellat, J. Phys. Chem. B, 2004, 108, 53335340.

41. N. Millot, D. Aymes, F. Bernard, J. C. Niepce, A. Traverse, F. Bourée, B. L. Cheng, and P. Perriat, J. Phys. Chem. B, 2003, 107, 5740-5750.

42. N. C. Halder and C. N. J. Wagner, in Advances in X-Ray Analysis, eds. G. R. Mallett, M. J. Fay, and W. M. Mueller, Springer US, 1966, pp. 91-102.

43. T. Belin, N. Millot, N. Bovet, and M. Gailhanou, J. Solid State Chem., 2007, 180, $2377-2385$.

44. P. Poix, Semin. Etat Solide, 1966, 1, 1966-1967.

45. J.-P. Jolivet, C. Chaneac, and E. Tronc, Chem. Commun. Camb. U. K., 2004, 481-487.

46. T. P. Raming, A. J. A. Winnubst, C. M. van Kats, and A. P. Philipse, J. Colloid Interface Sci., 2002, 249, 346-350.

47. M. Iwasaki, M. Hara, and S. Ito, J. Mater. Sci., 2000, 35, 943-949.

48. C. B. Xu and A. S. Teja, J. Supercrit. Fluids, 2006, 39, 135-141.

49. X. H. Liu, G. Z. Qiu, A. G. Yan, Z. Wang, and X. G. Li, J. Alloys Compd., 2007, 433, $216-220$.

50. A. Cabanas and M. Poliakoff, J. Mater. Chem., 2001, 11, 1408-1416.

51. K. C. Park, F. Wang, S. Morimoto, M. Fujishige, A. Morisako, X. X. Liu, Y. J. Kim, Y. C. Jung, I. Y. Jang, and M. Endo, Mater. Res. Bull., 2009, 44, 1443-1450.

52. M. D. de Tercero, M. Bruns, I. G. Martínez, M. Türk, U. Fehrenbacher, S. Jennewein, and L. Barner, Part. Part. Syst. Charact., 2013, 30, 229-234.

53. S. Takami, T. Sato, T. Mousavand, S. Ohara, M. Umetsu, and T. Adschiri, Mater. Lett., 2007, 61, 4769-4772.

54. E. Tronc, P. Belleville, J. P. Jolivet, and J. Livage, Langmuir, 1992, 8, 313-319.

55. J. P. Jolivet, P. Belleville, E. Tronc, and J. Livage, Clays Clay Miner., 1992, 40, 531-539. 